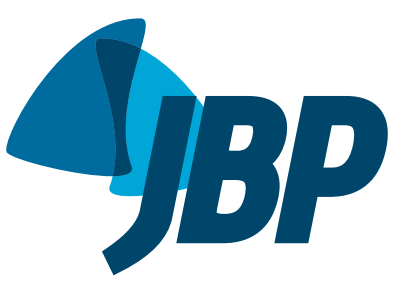

1. Divisão de Pneumologia, Instituto do Coração, Hospital das Clínicas, Faculdade de Medicina, Universidade de São Paulo, São Paulo (SP) Brasil.

2. Disciplina de Pneumologia, Faculdade de Medicina, Universidade de São Paulo, São Paulo (SP) Brasil.

3. Divisão de Diagnóstico por Imagem Instituto do Coração, Hospital das Clínicas, Faculdade de Medicina, Universidade de São Paulo, São Paulo (SP) Brasil.

4. Laboratório Experimental de Poluição Atmosférica, Departamento de Patologia, Faculdade de Medicina Universidade de São Paulo, São Paulo (SP) Brasil.

Submitted: 12 September 2016. Accepted: 31 October 2016

Study carried out at the Instituto do Coração, Hospital das Clínicas, Faculdade de Medicina, Universidade de São Paulo, São Paulo (SP) Brasil.

\title{
Hard metal lung disease: a case series
}

\author{
Rafael Futoshi Mizutani1, Mário Terra-Filho ${ }^{1,2}$, Evelise Lima', \\ Carolina Salim Gonçalves Freitas ${ }^{1}$, Rodrigo Caruso Chate ${ }^{3}$, \\ Ronaldo Adib Kairalla ${ }^{1,2}$, Regiani Carvalho-Oliveira ${ }^{4}$, Ubiratan Paula Santos ${ }^{1}$
}

\begin{abstract}
Objective: To describe diagnostic and treatment aspects of hard metal lung disease (HMLD) and to review the current literature on the topic. Methods: This was a retrospective study based on the medical records of patients treated at the Occupational Respiratory Diseases Clinic of the Instituto do Coração, in the city of São Paulo, Brazil, between 2010 and 2013. Results: Of 320 patients treated during the study period, 5 (1.56\%) were diagnosed with HMLD. All of those 5 patients were male (mean age, 42.0 \pm 13.6 years; mean duration of exposure to hard metals, $11.4 \pm 8.0$ years). Occupational histories were taken, after which the patients underwent clinical evaluation, chest HRCT, pulmonary function tests, bronchoscopy, BAL, and lung biopsy. Restrictive lung disease was found in all subjects. The most common chest HRCT finding was ground glass opacities (in $80 \%$ ). In 4 patients, BALF revealed multinucleated giant cells. In 3 patients, lung biopsy revealed giant cell interstitial pneumonia. One patient was diagnosed with desquamative interstitial pneumonia associated with cellular bronchiolitis, and another was diagnosed with a hypersensitivity pneumonitis pattern. All patients were withdrawn from exposure and treated with corticosteroid. Clinical improvement occurred in 2 patients, whereas the disease progressed in 3. Conclusions: Although HMLD is a rare entity, it should always be included in the differential diagnosis of respiratory dysfunction in workers with a high occupational risk of exposure to hard metal particles. A relevant history (clinical and occupational) accompanied by chest HRCT and BAL findings suggestive of the disease might be sufficient for the diagnosis.
\end{abstract}

Keywords: Lung diseases, interstitial; Cobalt; Tungsten; Occupational exposure; Hard metal.

\section{INTRODUCTION}

Hard metal lung disease (HMLD) is a rare disease caused by exposure to particles of hard metal alloys, whose major components are tungsten carbide (approximately 90\%) and cobalt (approximately $10 \%$ ) or cobalt and diamond. ${ }^{(1,2)}$ Other components, such as tantalum, titanium, nickel, niobium, and chrome, are found in small amounts.

Because they are extremely hard and maintain their physical properties even at high temperatures, hard metals are used in tools for cutting and sharpening metals, drilling wells, polishing diamonds and dental prostheses, etc. Workers are exposed to particles rich in cobalt (in ionized form) and tungsten carbide, which are absorbed by the lungs and gastrointestinal tract, both in cobalt powder production and when using cobalt alloy tools. The pathophysiology of HMLD remains unknown. The proposed mechanism for the pathogenesis of the interstitial disease involves a hypersensitivity reaction to cobalt. ${ }^{(3)}$ In addition, genetic susceptibility ${ }^{(4)}$ may play a role in the pathogenesis of the disease, although this role has yet to be fully understood.

Exposure to cobalt can cause several forms of lung disease, from asthma to various interstitial patterns in the lungs. ${ }^{(1)}$ The most widely known and typical histopathological presentation is giant cell interstitial pneumonia (GIP), described by Liebow ${ }^{(5)}$ in 1968. GIP is characterized by the presence of multinucleated giant cells, which can be "macrophagic" in nature, ${ }^{(1,6)}$ in alveolar spaces. In addition to GIP, other patterns described include usual interstitial pneumonia, hypersensitivity pneumonitis (HP), and desquamative interstitial pneumonia. ${ }^{(1,6)}$ In the present study, we describe diagnostic and treatment aspects of HMLD and review the current literature on the topic.

\section{METHODS}

The study subjects were treated at the Occupational Respiratory Diseases Clinic of the Pulmonology Division of the Instituto do Coração of the University of São Paulo School of Medicine Hospital das Clínicas, in the city of São Paulo, Brazil, between 2010 and 2013. Occupational histories were taken, after which all subjects underwent clinical evaluation, chest HRCT, pulmonary function tests (Elite DX Series, Medical Graphics Corporation, Saint Paul, MN, USA), bronchoscopy, BAL, and lung biopsy. When the lung tissue obtained was considered insufficient for diagnosis, surgical biopsies were performed. We performed elemental analysis of lyophilized lung tissue specimens by

Correspondence to:

Rafael Futoshi Mizutani. Instituto do Coração, Hospital das Clínicas, Faculdade de Medicina, Universidade de São Paulo, Avenida Dr. Enéas Carvalho de Aguiar, 44, Bloco II $5^{\circ}$ Andar, Pneumologia, Cerqueira César, CEP 05403-900, São Paulo (SP) Brasil.

Tel.: 5511 2661-5801. E-mail: rafael.mizutani@hc.fm.usp.br

Financial support: None. 
energy-dispersive $X$-ray fluorescence spectrometry ${ }^{(7)}$ in 2 patients (EDX 700-HS, Shimadzu Corporation, Analytical Instruments Division, Kyoto, Japan).

\section{RESULTS}

During the study period, 320 patients were treated at the facility. Of those, $5(1.56 \%)$ were diagnosed with HMLD. The mean age at diagnosis was $42.0 \pm$ 13.6 years. All of those 5 patients were male and were working at the time of the initial evaluation. The mean duration of exposure was $11.4 \pm 8.0$ years. One patient reported working as an industrial tool maintenance technician, 2 reported being industrial tool sharpeners, and 2 reported being grinder operators (Table 1). All 5 clinically presented with dyspnea on exertion and cough.

The most common chest HRCT finding was ground glass opacities, in 4 patients (80\%; Figure 1 ). Other findings included peripheral reticular opacities with traction bronchiectasis and bronchiolectasis, in 3 (60\%; Figure 2); micronodules, in 2 (40\%; Figure $2)$; and bronchial wall thickening, in 2 (40\%; Table 1). Restrictive lung disease, in varying degrees, was found in all subjects, and decreased DLCO was found in 3 (Table 2).

All patients underwent bronchoscopy, BAL, and lung biopsy, with the diagnosis being established by examination of a bronchoscopy specimen in 1 patient and by examination of a surgical biopsy specimen in 4. Large numbers of multinucleated giant cells were found in the BAL fluid of 4 of the 5 patients (Figure 3) and in the biopsy tissue of 3 (Figure 4). Desquamative interstitial pneumonia associated with cellular bronchiolitis was diagnosed in 1 patient; a histological pattern suggestive of chronic HP, with no evidence of other occupational or environmental exposures that could be associated with $\mathrm{HP}$, was identified in 1 ; the presence of tungsten was identified in 2 , whose tissue samples were analyzed by energy-dispersive X-ray fluorescence spectrometry; and the presence of cobalt was identified in 1 of those 2 (Table 1 ).

Following diagnosis, all patients were withdrawn from their occupational exposure and received systemic corticosteroid therapy. Two patients showed clinical, radiological, and functional improvement, although their lung function did not normalize (Tables 1 and 2 ). Three patients experienced disease progression despite corticosteroid therapy, 2 of whom additionally received azathioprine. One patient was placed on a lung transplant list, but he died before undergoing transplantation.

\section{DISCUSSION}

In the case series presented here, ground-glass opacities were the most common chest HRCT changes. Restrictive lung disease was the most common finding, occurring in all patients. Multinucleated giant cells were detected in the BAL fluid of most patients, and this finding was correlated with the typical histological pattern of GIP. Withdrawal from exposure combined with corticosteroid therapy was successful in 2 patients, and disease progression occurred in 3 patients.

The functional, cytological, histopathological, and imaging findings are similar to those found in other studies. ${ }^{(1,6,8)}$

HMLD is a rare entity, even in populations at occupational risk. The published literature on cases of HMLD in Brazil is scarce and consists of the reporting of the disease in 4 patients. ${ }^{(9-12)}$ In the literature, data on the prevalence and incidence of HMLD among individuals exposed to hard metals vary. Meyer-Bisch et al. ${ }^{(13)}$ and Kusaka et al. ${ }^{(14)}$ found no cases of HMLD in cross-sectional studies involving 425 and 319 workers, respectively, with a mean duration of exposure to hard metals of 9 and 14 years, respectively. Sprince et al. ${ }^{(15)}$ found only 1 patient with HMLD among 290 hard metal production workers evaluated. The diagnostic imaging methods available at the time might have contributed to the low HMLD detection results observed in those studies. ${ }^{(13-15)}$

The paucity of cases and the varying latency period suggest that a hypersensitivity mechanism may be involved in the pathophysiology of HMLD. Sabbioni et al. (3) found that $9 \%$ of the workers who had contact with hard metals had lung disease, and that the observed prevalence was not correlated with cobalt, tungsten, or tantalum levels, nor was it correlated with age, gender, or duration of occupational exposure, which, in the authors' view, reinforced the hypersensitivity hypothesis. Recurrence of HMLD in unilateral ${ }^{(16,17)}$ or bilateral(6) lung transplant recipients, even after cessation of exposure to hard metals, suggests the hypothesis that immune-mediated mechanisms are involved in the pathophysiology of the disease. In those 3 reported cases of recurrence, ${ }^{(6,16,17)}$ the histological pattern of GIP was found, and no traces of tungsten or cobalt were detected in the transplanted lungs, which, in the authors' view, reinforced this immune-mediated hypothesis.

Genetic susceptibility also contributes to the development of HMLD. Potolicchio et al. ${ }^{(4)}$ demonstrated that HLA-DP- $\beta$ Glu69 was more prevalent among hard-metal-exposed workers with HMLD than in those without. In that study, ${ }^{(4)} 19$ (95\%) of 20 hard-metal-exposed workers with HMLD exhibited this polymorphism, compared with $17(48.6 \%)$ of 35 hard-metal-exposed workers without the disease.

The individual contribution of the major components of hard metal has also been investigated. In animal models, instillation of tungsten alone did not produce pulmonary inflammation, whereas cobalt alone was able to produce tissue injury. When combined, cobalt and tungsten had a synergistic effect and caused increased tissue inflammation. ${ }^{(18,19)}$

Moriyama et al. ${ }^{(8)}$ performed electron microprobe analysis of elemental levels in 17 patients with HMLD and concluded that cobalt and tungsten accumulate in 
Table 1. Characteristics of the patients with hard metal lung disease.

\begin{tabular}{|c|c|c|c|c|c|}
\hline Characteristic & Case 1 & Case 2 & Case 3 & Case 4 & Case 5 \\
\hline Age, years & 44 & 30 & 30 & 43 & 63 \\
\hline Smoking & No & No & No & Former smoker & No \\
\hline Occupation & Grinder operator & Grinder operator & $\begin{array}{l}\text { Industrial tool } \\
\text { sharpener }\end{array}$ & $\begin{array}{l}\text { Industrial tool } \\
\text { sharpener }\end{array}$ & $\begin{array}{l}\text { Industrial tool } \\
\text { maintenance } \\
\text { technician }\end{array}$ \\
\hline $\begin{array}{l}\text { Duration of } \\
\text { exposure, years }\end{array}$ & 25 & 6 & 8 & 6 & 12 \\
\hline $\begin{array}{l}\text { Chest HRCT } \\
\text { findings }\end{array}$ & $\begin{array}{l}\text { Extensive ground- } \\
\text { glass opacities } \\
\text { and poorly defined } \\
\text { centrilobular } \\
\text { micronodules, } \\
\text { predominantly in } \\
\text { the middle and } \\
\text { upper lung fields. } \\
\text { Pattern suggestive } \\
\text { of subacute HP }\end{array}$ & $\begin{array}{l}\text { Fine reticulation, } \\
\text { ground-glass } \\
\text { opacities, } \\
\text { and traction } \\
\text { bronchiolectasis, } \\
\text { distributed } \\
\text { symmetrically } \\
\text { and mainly } \\
\text { peripherally, } \\
\text { predominantly in } \\
\text { the lung bases }\end{array}$ & $\begin{array}{c}\text { Interstitial } \\
\text { micronodular } \\
\text { infiltrates } \\
\text { distributed in a } \\
\text { perilymphatic } \\
\text { pattern, } \\
\text { predominantly in } \\
\text { the upper lung } \\
\text { fields }\end{array}$ & $\begin{array}{l}\text { Ground-glass } \\
\text { opacities, } \\
\text { peripheral } \\
\text { reticulation, } \\
\text { and traction } \\
\text { bronchiectasis and } \\
\text { bronchiolectasis, } \\
\text { predominantly } \\
\text { in the lower lung } \\
\text { fields }\end{array}$ & $\begin{array}{l}\text { Fine reticulation, } \\
\text { ground-glass } \\
\text { opacities, traction } \\
\text { bronchiectasis and } \\
\text { bronchiolectasis, } \\
\text { distributed } \\
\text { peripherally, and } \\
\text { an area of air } \\
\text { trapping in the } \\
\text { left lower lobe }\end{array}$ \\
\hline BAL pattern & $\begin{array}{l}\text { Multinucleated } \\
\text { giant cells }\end{array}$ & $\begin{array}{l}\text { Multinucleated } \\
\text { giant cells }\end{array}$ & $\begin{array}{l}\text { Multinucleated } \\
\text { giant cells }\end{array}$ & $\begin{array}{l}\text { Multinucleated } \\
\text { giant cells }\end{array}$ & Lymphocytic \\
\hline Type of biopsy & Surgical & Surgical & Transbronchial & Surgical & Surgical \\
\hline $\begin{array}{l}\text { Histological } \\
\text { pattern of the } \\
\text { biopsy specimen }\end{array}$ & $\begin{array}{l}\text { DIP and cellular } \\
\text { bronchiolitis }\end{array}$ & GIP & GIP & GIP & HP \\
\hline EDS results & $\begin{array}{c}\text { Cobalt + Tungsten } \\
+\end{array}$ & $\begin{array}{c}\text { Cobalt - Tungsten } \\
+\end{array}$ & NA & NA & NA \\
\hline Treatment & $\begin{array}{c}\text { Corticosteroid } \\
\text { therapy, } \\
\text { azathioprine }\end{array}$ & $\begin{array}{c}\text { Corticosteroid } \\
\text { therapy }\end{array}$ & $\begin{array}{c}\text { Corticosteroid } \\
\text { therapy }\end{array}$ & $\begin{array}{l}\text { Corticosteroid } \\
\text { therapy, } \\
\text { azathioprine, } \\
\text { placement on a } \\
\text { lung transplant } \\
\text { list }\end{array}$ & $\begin{array}{l}\text { Corticosteroid } \\
\text { therapy }\end{array}$ \\
\hline Patient course & Worsening & Improvement & Improvement & Death & Worsening \\
\hline
\end{tabular}

DIP: desquamative interstitial pneumonia; GIP: giant cell interstitial pneumonia; HP: hypersensitivity pneumonitis; EDS: energy-dispersive X-ray fluorescence spectrometry; and NA: not assessed.
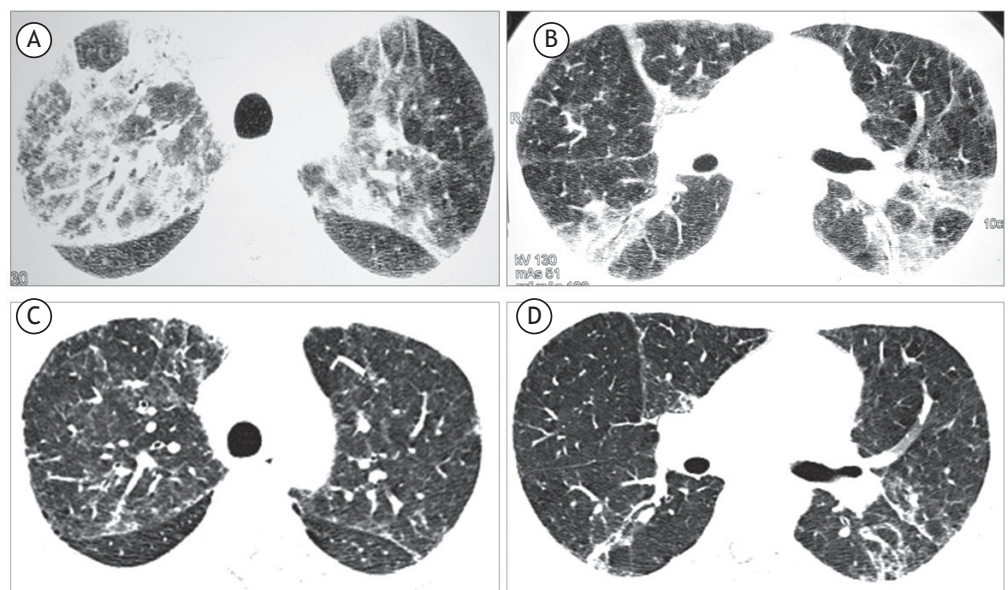

Figure 1. HRCT scans. Case 2, before treatment initiation (Figures A and B): ground-glass opacities and parenchymal consolidations with some air bronchograms in both lungs, predominantly in the middle and upper lung fields, in a pattern similar to that of organizing pneumonia. Case 2, after treatment (Figures C and D): the pulmonary changes were significantly reduced, there now being subtle foci of ground-glass opacification, mild, poorly defined centrilobular nodules, and scattered linear opacities, bilaterally.

centrilobular fibrotic lesions. In that study, immunohistochemistry revealed the presence of tungsten particles within lesions surrounded by CD163+ macrophages and T CD8+ lymphocytes. The authors ${ }^{(8)}$ suggest that such macrophages play an important role in the development of fibrotic lesions. 

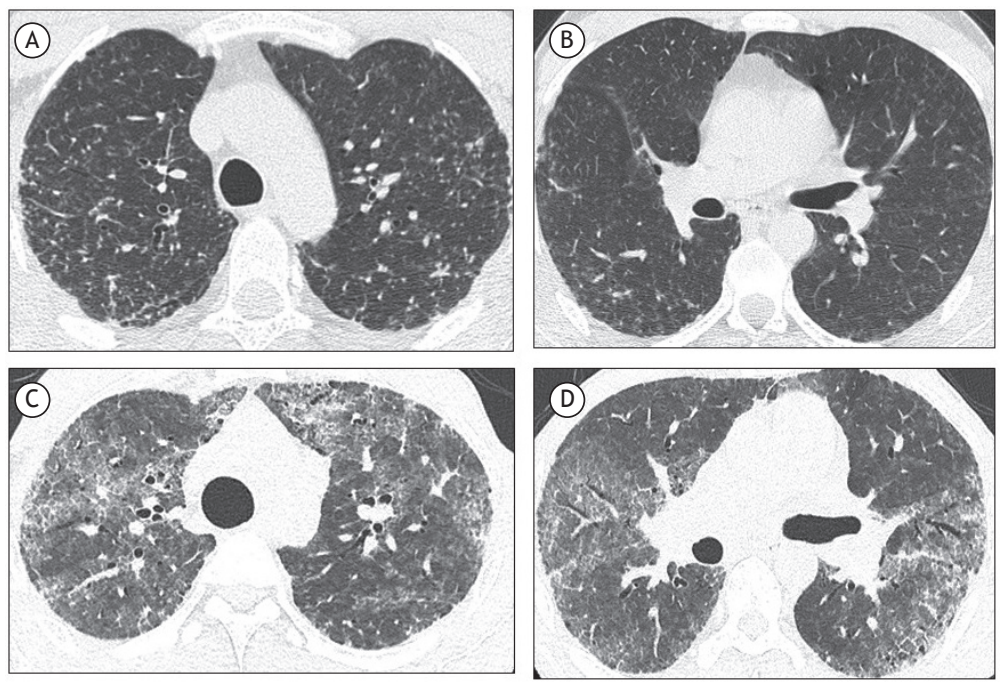

Figure 2. HRCT scans. Case 3 (Figures A and B): micronodular opacities distributed in a perilymphatic pattern, predominantly in the middle and upper lung fields. Case 4 (Figures $C$ and D): ground-glass opacities and foci of parenchymal consolidation, predominantly in the middle and upper lung fields, as well as mild peripheral reticulation with traction bronchiectasis and bronchiolectasis.

Table 2. Course of lung function in the study subjects. ${ }^{a}$

\begin{tabular}{lcccccccccc}
\multicolumn{1}{c}{ Variable } & \multicolumn{2}{c}{ Case 1 } & \multicolumn{2}{c}{ Case 2 } & \multicolumn{2}{c}{ Case 3 } & \multicolumn{2}{c}{ Case 4 } & \multicolumn{2}{c}{ Case 5 } \\
& Baseline & After & Baseline & After & Baseline & After & Baseline & After & Baseline & After \\
& & $14 \mathrm{~m}$ & & $60 \mathrm{~m}$ & & $56 \mathrm{~m}$ & & $30 \mathrm{~m}$ & & $24 \mathrm{~m}$ \\
$\mathrm{FVC}, \mathrm{L}$ & 4.17 & 3.74 & 2.85 & 2.88 & 3.47 & 4.12 & 2.22 & 1.76 & 2.81 & 2.33 \\
& $(79 \%)$ & $(67 \%)$ & $(63 \%)$ & $(59 \%)$ & $(63 \%)$ & $(76 \%)$ & $(49 \%)$ & $(39 \%)$ & $(83 \%)$ & $(61 \%)$ \\
$\mathrm{FEV}_{1}, \mathrm{~L}$ & 3.54 & 3.20 & 2.45 & 2.38 & 2.73 & 3.08 & 2.09 & 1.70 & 2.32 & 1.94 \\
& $(83 \%)$ & $(73 \%)$ & $(65 \%)$ & $(60 \%)$ & $(60 \%)$ & $(68 \%)$ & $(56 \%)$ & $(46 \%)$ & $(86 \%)$ & $(69 \%)$ \\
$\mathrm{FEV}_{1} / \mathrm{FVC}$ & 0.85 & 0.86 & 0.86 & 0.83 & 0.81 & 0.75 & 0.94 & 0.94 & 0.82 & 0.83 \\
$\mathrm{TLC}, \mathrm{L}$ & $\mathrm{NA}$ & 5.57 & 4.31 & 5.11 & 5.19 & 5.89 & 3.80 & $\mathrm{NA}$ & 4.07 & 4.06 \\
& & $(75 \%)$ & $(68 \%)$ & $(83 \%)$ & $(66 \%)$ & $(75 \%)$ & $(56 \%)$ & & $(65 \%)$ & $(65 \%)$ \\
$\mathrm{RV}, \mathrm{L}$ & $\mathrm{NA}$ & 1.84 & 1.56 & 2.09 & 1.47 & 1.83 & 1.54 & $\mathrm{NA}$ & 1.29 & 1.67 \\
& & $(91 \%)$ & $(96 \%)$ & $(142 \%)$ & $(79 \%)$ & $(98 \%)$ & $(77 \%)$ & & $(54 \%)$ & $(76 \%)$ \\
$\mathrm{DLCO}$, & $\mathrm{NA}$ & $\mathrm{NA}$ & 22.76 & 28.89 & 32.44 & 43.25 & 6.15 & $\mathrm{NA}$ & 19.39 & 11.29 \\
$\mathrm{~mL} / \mathrm{min} / \mathrm{mmHg}$ & & & $(72 \%)$ & $(106 \%)$ & $(93 \%)$ & $(107 \%)$ & $(20 \%)$ & & $(67 \%)$ & $(39 \%)$ \\
\hline
\end{tabular}

m: months; and NA: not assessed. aPercent predicted values calculated for the Brazilian population according to Neder et al.(32)

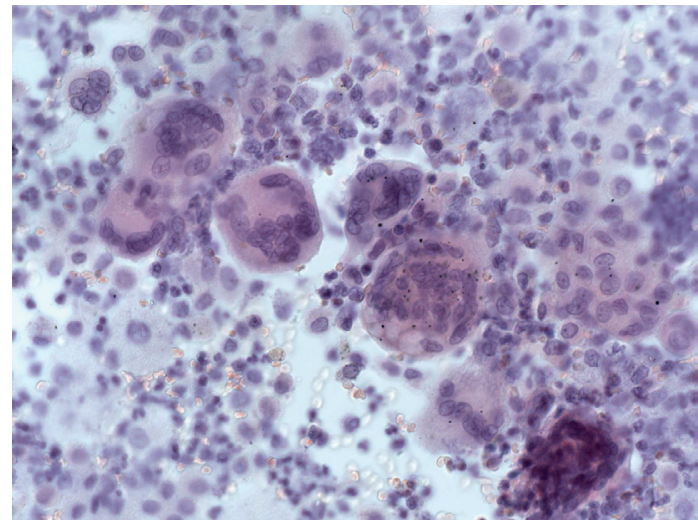

Figure 3. BAL specimen containing macrophages, neutrophils, and lymphocytes, as well as multinucleated giant cells (Papanicolaou stain; magnification, $\times 400$ ).

The clinical presentation of HMLD varies widely, as shown in this case series. The initial symptom is usually dyspnea on exertion. Patients who have HMLD

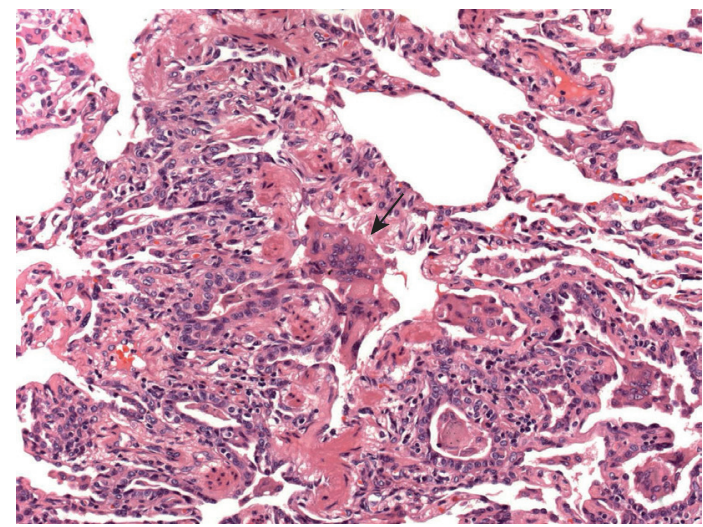

Figure 4. Histological analysis of a lung biopsy specimen. Respiratory bronchiole stripped of its lining epithelium, filled with multinucleated giant cells (arrow), also observed in the adjacent alveoli, which are covered by metaplastic columnar epithelium (H\&E; magnification, $\times 200$ ).

develop restrictive lung disease and have a reduction in DLCO, of varying severity. ${ }^{(1)}$ 
A relevant clinical and occupational history is essential for the diagnosis of HMLD. Although chest X-ray and HRCT findings are nonspecific, they are important in diagnosis, together with a history of exposure and histopathological changes. The major chest HRCT changes found by Choi et al. ${ }^{(20)}$ were ground-glass opacities and irregular linear opacities, predominantly in the lower lung fields; these changes were also commonly seen in the 5 cases described here.

Unlike in other pneumoconioses, in which, in most cases, relevant occupational history and suggestive chest X-ray findings are sufficient to establish the diagnosis, in HMLD, chest HRCT and a specimen for cytological or histological analysis are required. BAL, which is a minimally invasive method, can confirm the diagnosis without the need for lung biopsy. ${ }^{(1,21)}$

Forni, ${ }^{(21)}$ in reviewing BAL cytopathological findings described in the literature, concluded that there are two patterns that suggest the diagnosis of HMLD. The first is characterized by significantly increased cellularity, resulting from characteristic multinucleated giant cells, lymphocytosis with a decreased CD4/CD8 ratio, and eosinophilia. To Forni, (21) these findings mirror the histopathological findings of GIP, and, in such cases, a lung tissue biopsy would not be required. The second BAL pattern is that of predominant lymphomononuclear infiltrates, with a decreased CD4/CD8 ratio, rare eosinophils, and giant cells, being similar to the pattern found in HP. In such cases, biopsy is essential to establish the diagnosis. ${ }^{(21)}$

In the present case series, the BAL patterns coincided with those described by Forni ${ }^{(21)}$ and reinforce the relationship between the presence of multinucleated giant cells in the BAL and the histological diagnosis of GIP.

Naqvi et al., (1) in a review of 100 patients who had undergone lung biopsy and had a diagnosis of HMLD, reported that 59 of those patients had the pattern of GIP, defined as the presence of typical multinucleated giant cells in the alveolar space. Moriyama et al. ${ }^{(8)}$ highlighted the importance of the presence of centrilobular fibrotic lesions in the histological specimen for the diagnosis of HMLD, even when there are no multinucleated giant cells. Another histopathological pattern that is seen is that of HP. ${ }^{(1,22)}$ Hard-metal-exposed workers often also use cutting oil, which may be contaminated with Mycobacterium immunogenum, whose antigens can cause HP. ${ }^{(23)}$
When the observed histological patterns are inconsistent with GIP, elemental analysis, by a combination of electron microscopy and energy-dispersive X-ray fluorescence spectrometry, is important in establishing the diagnosis. ${ }^{(1)}$ Tungsten is usually found at high levels, ${ }^{(1,8,24)}$ whereas cobalt is usually found at moderate or low levels, since cobalt is highly soluble and is eliminated rapidly. ${ }^{(1,3)}$

Although some authors have suggested that GIP is a pathognomonic finding of HMLD, ${ }^{(25)}$ there have been several published reports of cases ${ }^{(1,6,8)}$ with a histological pattern of GIP without occupational exposure to hard metals and without tungsten or cobalt being detected in lung tissue. Other authors ${ }^{(8,26)}$ have suggested that such cases correspond to idiopathic GIP. Other reported cases of GIP have been associated with exposure to titanium $^{(27)}$ and to nitrofurantoin. (28)

Treatment of HMLD consists of withdrawal from the occupational exposure, which can stabilize or even improve lung function, ${ }^{(29)}$ and corticosteroid therapy. Because of the scarcity of cases in the literature, there have been no studies comparing corticosteroid therapy and placebo treatment; however, clinical experience is that corticosteroid therapy results in improvement. $(9,30)$ The use of immunosuppressive therapy also is not well established, although immunosuppressants are occasionally used. ${ }^{(9)}$ Lung transplantation is a treatment option in patients with advanced lung disease that progresses despite treatment, ${ }^{(31)}$ despite the possibility of GIP pattern recurrence in the transplanted lung. $(6,16,17)$

Although HMLD is rare, it should always be included in the differential diagnosis of respiratory dysfunction in hard-metal-exposed workers-such as tool sharpeners, toolmakers, operators of machines (such as milling cutters, grinders, and lathes), operators of diamond-blade cutting discs, and diamond polishers (using polishing discs made of hard metals)-who present with clinical complaints, functional changes, or imaging changes. Data in the literature and our experience with the cases reported here suggest that adequate occupational history taking accompanied by chest HRCT changes and BAL findings (lymphocytosis with a decreased CD4/CD8 ratio and, especially, the presence of large numbers of giant cells) consistent with the disease might be sufficient for the diagnosis, there being no need for an open lung biopsy. Treatment is based on permanent withdrawal from exposure and corticosteroid or immunosuppressive therapy, with varying results.

\section{REFERENCES}

1. Naqvi $A H$, Hunt $A$, Burnett BR, Abraham JL. Pathologic spectrum and lung dust burden in giant cell interstitial pneumonia (hard metal disease/cobalt pneumonitis): review of 100 cases. Arch Environ Occup Health. 2008;63(2):51-70. https:/doi.org/10.3200/ AEOH.63.2.51-70

2. Palmen N. Criteria Document for Swedish Occupational Standards: Cobalt and Cobalt Compounds. Stockholm: Swedish National Institute for Working Life, Swedish Criteria Group for Occupational Standards; 2015. Report No.: NR 2005:12.

3. Sabbioni E, Minoia C, Pietra R, Mosconi G, Forni A, Scansetti G.
Metal determinations in biological specimens of diseased and nondiseased hard metal workers. Sci Total Environ. 1994;150(1-3):41-54. https:/doi.org/10.1016/0048-9697(94)90127-9

4. Potolicchio I, Mosconi G, Forni A, Nemery B, Seghizzi P, Sorrentino R Susceptibility to hard metal lung disease is strongly associated with the presence of glutamate 69 in HLA-DP beta chain. Eur J Immunol. 1997;27(10):2741-3. https:/doi.org/10.1002/eji.1830271039

5. Liebow A. New Concepts and Entities in Pulmonary Disease in the Lung. Baltimore, MD: Williams and Wilkins; 1968. p. 332

6. Khoor A, Roden AC, Colby TV, Roggli VL, Elrefaei M, Alvarez F et 
al. Giant cell interstitial pneumonia in patients without hard metal exposure: analysis of 3 cases and review of the literature. Hum Pathol. 2016;50:176-82. https:/doi.org/10.1016/j.humpath.2015.12.004

7. Carneiro MF, Ribeiro FQ, Fernandes-Filho FN, Lobo DJ, Barbosa F Jr, Rhoden $\mathrm{CR}$, et al. Pollen abortion rates, nitrogen dioxide by passive diffusive tubes and bioaccumulation in tree barks are effective in the characterization of air pollution. Environ Exp Bot. 2011;72(2):272-7. https:/doi.org/10.1016/j.envexpbot.2011.04.001

8. Moriyama H, Kobayashi M, Takada T, Shimizu T, Terada M, Narita J et al. Two-dimensional analysis of elements and mononuclear cells in hard metal lung disease. Am J Respir Crit Care Med. 2007;176(1):707. https:/doi.org/10.1164/rccm.200601-1340C

9. Bezerra PN, Vasconcelos AG, Cavalcante LL, Marques VB, Nogueira TN, Holanda MA. Hard metal lung disease in an oil industry worker J Bras Pneumol. 2009;35(12):1254-8.

10. Moreira MA, Cardoso Ada R, Silva DG, Queiroz MC, Oliveira AA Noleto TM. Hard metal pneumoconiosis with spontaneous bilatera pneumothorax. J Bras Pneumol. 2010;36(1):148-151. https:/doi. org/10.1590/S1806-37132010000100020

11. De Capitani EM, Schweller M, Grangeial TA, Corso-Pereira M Cerqueira EM, Metze K, et al. Pneumonia intersticial descamativa secundária a exposição à poeira de metal duro. Pneumologia Paulista, 2010;24(11):62-3.

12. De Capitani EM, Corso-Pereira M, Saldiva PH. Hard metal subacute pneumopathy: a case report. In: Proceedings of the 8th International Conference on Occupational Lung Diseases; 1992 Sep 14-17 Prague. ILO and Czech Medical Society; 1993

13. Meyer-Bisch C, Pham QT, Mur JM, Massin N, Moulin JJ, Teculescu $D$, et al. Respiratory hazards in hard metal workers: a cross sectional study. Br J Ind Med. 1989;46(5):302-9. https:/doi.org/10.1136/ oem.46.5.302

14. Kusaka Y, Yokoyama K, Sera Y, Yamamoto S, Sone S, Kyono H et al. Respiratory diseases in hard metal workers: an occupational hygiene study in a factory. $\mathrm{Br} \mathrm{J}$ Ind Med. 1986;43(7):474-85. https:/ doi.org/10.1136/oem.43.7.474

15. Sprince NL, Chamberlin RI, Hales CA, Weber AL, Kazemi $H$ Respiratory disease in tungsten carbide production workers. Chest. 1984;86(4):549-57. https:/doi.org/10.1378/chest.86.4.549

16. Frost AE, Keller CA, Brown RW, Noon GP, Short HD, Abraham JL, et al. Giant cell interstitial pneumonitis. Disease recurrence in the transplanted lung. Am Rev Respir Dis. 1993;148(5):1401-4. https: doi.org/10.1164/ajrccm/148.5.1401

17. Tarabichi Y, Saggar R, Wallace WD, Lynch JP 3rd, Saggar R. Primary disease recurrence after single lung transplantation in a patient with prior hard metal exposure. J Heart Lung Transplant. 2015;34(9):1216 8. https:/doi.org/10.1016/j.healun.2015.05.019

18. Kaplun ZS, Mezencheva NV. Experimental study on the toxic effect of dust in production of sintered metals [Article in German]. J Hyg Epidemiol Microbiol Immunol. 1960;4:390-9.

19. Lasfargues G, Lardot C, Delos M, Lauwerys R, Lison D. The delayed lung responses to single and repeated intratracheal administration of pure cobalt and hard metal powder in the rat. Environ Res.
1995;69(2):108-21. https:/doi.org/10.1006/enrs.1995.1032

20. Choi JW, Lee KS, Chung MP, Han J, Chung MJ, Park JS. Giant cel interstitial pneumonia: high-resolution CT and pathologic findings in four adult patients. Am J Roentgenol. 2005;184(1):268-72. https:/doi. org/10.2214/ajr.184.1.01840268

21. Forni A. Bronchoalveolar lavage in the diagnosis of hard meta disease. Sci Total Environ. 1994;150(1-3):69-76. https:/doi. org/10.1016/0048-9697(94)90131-7

22. Okuno K, Kobayashi K, Kotani Y, Ohnishi H, Ohbayashi C, Nishimura $Y$. A case of hard metal lung disease resembling a hypersensitive pneumonia in radiological images. Inter Med. 2010:49(12):1185-9. https:/doi.org/10.2169/internalmedicine.49.3049

23. Tillie-Leblond I, Grenouillet F, Reboux G, Roussel S, Chouraki B Lorthois $\mathrm{C}$, et al. Hypersensitivity pneumonitis and metalworking fluids contaminated by mycobacteria. Eur Respir J. 2011;37(3):6407. https:/doi.org/10.1183/09031936.00195009

24. Tanaka J, Moriyama H, Terada M, Takada T, Suzuki E, Narita I, et al. An observational study of giant cell interstitial pneumonia and lung fibrosis in hard metal lung disease. BMJ Open. 2014;4(3):e004407. https:/doi.org/10.1136/bmjopen-2013-004407

25. Abraham JL. Lung pathology in 22 cases of giant cell interstitia pneumonia (GIP) suggests GIP is pathognomonic of cobalt (hard metal) disease [abstract]. Chest. 1987;91:312.

26. Blanc PD. Is giant cell interstitial pneumonitis synonymous with hard metal lung disease? Am J Respir Crit Care Med. 2007;176(8): 834; author reply 834-5. https:/doi.org/10.1164/ajrccm.176.8.834

27. Paris C, Pairon JC, Billon-Galland MA, Vanoni-Espiand H, Godbert $B$, Martinet $Y$, et al. Giant cell interstitial pneumonia: report of two cases with high titanium concentration in the lung. Am J Respi Crit Care Med. 2011;184(11):1315-7. https:/doi.org/10.1164/ ajrcm.184.11.1315a

28. Lee B, Balavenkataraman A, Sanghavi D, Walter K. Recurrent nitrofurantoin-induced giant cell interstitial pneumonia: case report and literature review. Respir Med Case Rep. 2015;14:49-52. https:/ doi.org/10.1016/j.rmcr.2015.01.002

29. Terui H, Konno S, Kaga K, Matsuno Y, Hatanaka KC, Kanno H, et al Two cases of hard metal lung disease showing gradual improvement in pulmonary function after avoiding dust exposure. J Occup Med Toxicol. 2015;10:29. https:/doi.org/10.1186/s12995-015-0070-9

30. Enriquez LS, Mohammed TL, Johnson GL, Lefor MJ, Beasley MB. Hard metal pneumoconiosis: a case of giant-cell interstitia pneumonitis in a machinist. Respir Care. 2007:52(2):196-9.

31. Weill D, Bender C, Corris PA, Dark JH, Davis RD, Keshavjee S, et al. A consensus document for the selection of lung transplant candidates: 2014-an update from the Pulmonary Transplantation Council of the International Society for Heart and Lung Transplantation. $J$ Heart Lung Transplant. 2015;34(1):1-15. https:/doi.org/10.1016/j. healun.2014.06.014

32. Neder JA, Andreoni S, Castelo-Filho A, Nery LE. Reference values for lung function tests. I. Static volumes. Braz J Med Biol Res. 1999;32(6):703-17. https:/doi.org/10.1590/s0100$879 \times 1999000600006$ 